\title{
Effect of Iron and Zinc Enriched Organics on Growth, Yield Attributes and Yield of Wheat in Loamy Sand
}

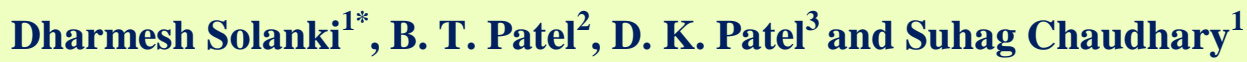 \\ ${ }^{1}$ Department Agricultural Chemistry and of Soil Science, C. P. College of Agriculture, \\ ${ }^{2}$ Bio Science Research Centre, \\ S. D. Agricultural University, Sardarkrushinagar-385 506 (Gujarat), India \\ ${ }^{3}$ State Council of Agricultural Universities, Krushibhavan, \\ Sector-10 A, Gandhinagar-382010 (Gujarat), India \\ *Corresponding author
}

Keywords

Iron, Zinc, FYM,

Vermicompost,

Wheat, Yield

Article Info

Accepted:

14 May 2020

Available Online:

10 June 2020

\section{A B S T R A C T}

A field experiment was carried at the Agronomy Instructional Farm, Department of Agronomy, Chimanbhai Patel College of Agriculture, Sardarkrushinagar Dantiwada Agricultural University, Sardarkrushinagar to study the effect of iron and zinc enriched organics on growth, yield attributes and yield of wheat(Triticum aestivum L.) in loamy sand (Typic Ustipsamments) during rabi season of 2017-18.The results revealed that an application of vermicompost @ $0.2 \mathrm{t} \mathrm{ha}^{-1}$ enriched with $5.00 \mathrm{~kg} \mathrm{Fe}$ and 2.50 $\mathrm{kg} \mathrm{Zn}$ in conjunction with recommended dose of fertilizer (RDF) significantly improved growth and yield attributes viz. plant height, number of effective tillers per meter row length, length of earhead, number of grains per earhead, 1000 grain weight and grain and straw yield of wheat as compared to control (RDF).

\section{Introduction}

Micronutrient deficiencies in Indian soils and crops have been on the increase since the adoption of modern agricultural technology with increased use of NPK fertilizers generally free from micronutrients, intensive cultivation with fertilizer responsive improved varieties of crops with more irrigation facilities, limited use of organic manure and restricted recycling of crop residues (Prasad, 1999). On the basis of 7587 soil samples collected from different districts of Gujarat, it was found that 25.9 and 25.6 per cent samples were deficient in $\mathrm{Fe}$ and $\mathrm{Zn}$, respectively (Patel et al., 2018). Desai et al., (2018) collected 556 soil samples from different talukas of Banaskantha district and 
found that 34.8 and 37.6 per cent samples were deficient in $\mathrm{Fe}$ and $\mathrm{Zn}$, respectively. Iron and zinc deficiencies are common micronutrient deficiency in light textured soils of North Gujarat limiting both crop production and nutrition quality.

The deficiencies of micronutrients have become major constraint for maintaining productivity of soil. Physical mixture of fertilizer with organic is supposed to be inferior compared to the addition of micronutrients to the soil in naturally chelated form with organics. The process of enrichment of organics with micronutrients not only improves the nutrient use efficiency but also helps in reducing the load of inorganic chemicals as well as quantity of organics to considerable extent (Meena et al., 2006).

The enrichment technique improves the quality of organics and therefore the addition of organics in lower quantities is expected to yield the similar effect on soil properties to that of use of FYM / vermicompost in higher quantities (without enrichment). It is very well known that when nutrients are chelated with organics, their use efficiency increases.The information on $\mathrm{Fe}$ and $\mathrm{Zn}$ enriched organics (FYM/Vermicompost) in different crops are rare and scare, especially in wheat crop practiced on $\mathrm{Fe}$ and $\mathrm{Zn}$ deficient soil of Banaskantha of North Gujarat. Present study was aimed at assessing the effect of $\mathrm{Fe}$ and $\mathrm{Zn}$ enriched organics on growth, yield attributes and yield of wheat crop.

\section{Materials and Methods}

A field experiment was conducted on a $\mathrm{Fe}$ and $\mathrm{Zn}$ deficient loamy sand (Typic Ustipsamments) soil during rabi season of 2017-18 atAgronomy Instructional Farm, Chimanbhai Patel College of Agriculture,
Sardarkrushinagar Dantiwada Agricultural University, Sardarkrushinagar. The soil of experimental field was low in organic carbon, available $\mathrm{N}$ and DTPA-extractable $\mathrm{Fe}$ and $\mathrm{Zn}$; medium in available $\mathrm{P}_{2} \mathrm{O}_{5}, \mathrm{~K}_{2} \mathrm{O}$ and $\mathrm{S}$ whereas high in DTPA-extractable $\mathrm{Mn}$ and $\mathrm{Cu}$ content. Ten treatments viz., RDF $\left(\mathrm{T}_{1}\right)$, $\mathrm{RDF}+5 \mathrm{t} \mathrm{FYM} \mathrm{ha}^{-1}\left(\mathrm{~T}_{2}\right), \mathrm{RDF}+2 \mathrm{t} \mathrm{VC}$ ha ${ }^{1}\left(\mathrm{~T}_{3}\right), \mathrm{RDF}+5 \mathrm{t} \mathrm{FYM} \mathrm{ha}^{-1}+2 \mathrm{t} \mathrm{VC} \mathrm{ha}^{-1}\left(\mathrm{~T}_{4}\right)$, $\mathrm{RDF}+0.5 \mathrm{t} \mathrm{FYM} \mathrm{ha}{ }^{-1}+5.00 \mathrm{~kg}$ Feand 2.50 $\mathrm{kg} \mathrm{Zn} \mathrm{ha}{ }^{-1}\left(\mathrm{~T}_{5}\right), \mathrm{RDF}+0.2 \mathrm{t} \mathrm{VC} \mathrm{ha}^{-1}+5.00$ $\mathrm{kg}$ Feand $2.50 \mathrm{~kg} \mathrm{Zn} \mathrm{ha}{ }^{-1}\left(\mathrm{~T}_{6}\right), \mathrm{RDF}+0.5 \mathrm{t}$ FYM ha ${ }^{-1}$ enriched with $5.00 \mathrm{~kg} F$ and 2.50 $\mathrm{kg} \mathrm{Zn}\left(\mathrm{T}_{7}\right), \mathrm{RDF}+0.2 \mathrm{t} \mathrm{VC} \mathrm{ha}^{-1}$ enriched with $5.00 \mathrm{~kg} \mathrm{Fe}$ and $2.50 \mathrm{~kg} \mathrm{Zn}\left(\mathrm{T}_{8}\right), \mathrm{RDF}+0.5 \mathrm{t}$ FYM ha ${ }^{-1}$ enriched with $2.50 \mathrm{~kg} \mathrm{Fe}$ and 1.25 $\mathrm{kg} \mathrm{Zn}\left(\mathrm{T}_{9}\right), \mathrm{RDF}+0.2 \mathrm{t} \mathrm{VC} \mathrm{ha}{ }^{-1}$ enriched with $2.50 \mathrm{~kg}$ Fe and $1.25 \mathrm{~kg} \mathrm{Zn}\left(\mathrm{T}_{10}\right)$ were laid out under randomized block design with four replications.

The enrichment process was started 45 days before their use in rabi experiment on wheat. The quantity of FYM $\left(0.5 \mathrm{t} \mathrm{ha}^{-1}\right)$ and vermicompost $\left(0.2 \mathrm{t} \mathrm{ha}^{-1}\right)$ were thoroughly mixed with $1 \%$ cow dung slurry and andthe solution of $\mathrm{FeSO}_{4} \cdot 7 \mathrm{H}_{2} \mathrm{O}$ and $\mathrm{ZnSO}_{4} \cdot 7 \mathrm{H}_{2} \mathrm{O}$ having required concentration as per the enrichment treatments viz., $5.00 \mathrm{~kg} \mathrm{Fe}+2.50$ $\mathrm{kg} \mathrm{Zn}$ and $2.50 \mathrm{~kg} \mathrm{Fe}+1.25 \mathrm{~kg} \mathrm{Zn}$. The moisture percentage of FYM and vermicompost after mixing with $\mathrm{FeSO}_{4} \cdot 7 \mathrm{H}_{2} \mathrm{O}$ and $\mathrm{ZnSO}_{4} \cdot 7 \mathrm{H}_{2} \mathrm{O}$ were kept at about 75 to 80 .

The mixtures were filled in pre-dug pit and pit was covered with polythene sheet and allowed for decomposition. The mixture was turned over periodically (weekly) and moisture level was maintained. The data for total $\mathrm{N}, \mathrm{P}_{2} \mathrm{O}_{5}, \mathrm{~K}_{2} \mathrm{O}, \mathrm{Fe}$ and $\mathrm{Zn}$ content of FYM and vermicompost before and after enrichment are given in Table 1. The Fe and $\mathrm{Zn}$ enriched organics were used in a field experiment. Farm yard manure $(0.5$ and $5.0 \mathrm{t}$ $\left.\mathrm{ha}^{-1}\right)$ and vermicompost $\left(0.2\right.$ and $\left.2.0 \mathrm{t} \mathrm{ha}^{-1}\right)$ were applied as per treatment in experiment. 
The entire quantity of phosphorus $\left(60 \mathrm{~kg} \mathrm{ha}^{-1}\right)$ and half quantity nitrogen $\left(60 \mathrm{~kg} \mathrm{ha}^{-1}\right)$ were applied uniformly in opened furrow in the form of diammonium phosphate and urea, respectively. As per treatment, the required quantity of $\mathrm{Fe}$ and $\mathrm{Zn}$ in the form of $\mathrm{FeSO}_{4} .7 \mathrm{H}_{2} \mathrm{O} \quad(19 \% \quad \mathrm{Fe})$ and $\mathrm{ZnSO}_{4} .7 \mathrm{H}_{2} \mathrm{O}$ $(21 \% \mathrm{Zn})$ were applied in furrow, respectively. After that, application of $\mathrm{Fe}$ and $\mathrm{Zn}$ enriched FYM or vermicompost were applied in furrow as per the treatments. After fertilizer application, the furrows were covered with the soil in such a way that the furrow remained partly open for seed sowing. The remaining half dose of nitrogen $(60 \mathrm{~kg}$ $\mathrm{ha}^{-1}$ ) was top dressed in the form of urea after first irrigation.

Wheat variety GW 451 was sown in rows at $22.5 \mathrm{~cm}$ apart with $120 \mathrm{~kg}$ seed $\mathrm{ha}^{-1}$. Number of plants per meter row length and numbers of effective tillers per meter length were counted from randomly five spot of each net plot area just before harvest of crop. The average value was worked out. The observation on growth and yield attributes such as plant height and length of earhead in centimeter was recorded from five randomly selected plant from each net plot at physiological maturity stage and average value for such treatment was workout.

The earhead of the five selected plants were threshed separately and the numbers of grains were counted from each earhead and the mean values were recorded. The produce from each net plot area was threshed separately. After winnowing from each net plot were weighed separately and recorded in $\mathrm{kg}$ per net plot. The grain weights of earlier threshed five plants for each treatment were also added to respective net plot for each treatment. Thereafter it was converted into kilogram per hectare. A composite sample of grains was collected from the produce of each net plot and one thousand grains were counted using seed counter and then weighed 1000-grain by using electronic balance. Straw yield was obtained by subtracting the grain yield of each net plot from their respective biological yield and recorded separately for each treatment along with straw yield of tagged five plants and converted into kilogram per hectare.

\section{Results and Discussion}

\section{Growth and yield attributes}

The data presented in Table 2revealed that different treatments did not exert any significant influence on plant population per meter row length at harvest. The results clearly indicated that plant populations per meter row length in experimental plot were uniform. Hence, various growth and yield attributes of crop was not influenced due to variation in the plant population.

Among different treatment tested, the treatment receiving recommended dose of fertilizer along with $0.2 \mathrm{t}$ vermicompost $\mathrm{ha}^{-1}$ enriched with $5.00 \mathrm{~kg} \mathrm{Fe}$ and $2.50 \mathrm{~kg} \mathrm{Zn}$ in conjunction with RDF recorded significantly higher plant height, number of effective tillers per meter row length at harvest and length of earhead than the other treatments but it was found at par with treatment receiving $\mathrm{RDF}+$ $0.2 \mathrm{t}$ vermicompost ha ${ }^{-1}$ enriched with $2.50 \mathrm{~kg}$ $\mathrm{Fe}$ and $1.25 \mathrm{~kg} \mathrm{Zn}$ and RDF + $0.5 \mathrm{t} \mathrm{FYM} \mathrm{ha}^{-1}$ enriched with either $5.00 \mathrm{~kg} \mathrm{Fe}+2.50 \mathrm{~kg} \mathrm{Zn}$ or $2.50 \mathrm{~kg} \mathrm{Fe}+1.25 \mathrm{~kg} \mathrm{Zn}$. The maximum grains per earhead and 1000 grain weight were recorded under treatment of RDF $+0.2 \mathrm{t}$ vermicompost enriched with $5.00 \mathrm{~kg}$ Fe and $2.50 \mathrm{~kg} \mathrm{Zn}$. The minimum plant height was recorded under treatment receiving $\operatorname{RDF}\left(\mathrm{T}_{1}\right)$.

The observed significant increase in growth and yield attributes such as plant height, number of effective tillers per meter row length at harvest, length of earhead, number of grains per earhead and 1000 grain weight 
under treatments of $0.2 \mathrm{t}$ vermicompost or 0.5 t FYM enriched with either $5.00 \mathrm{~kg} F e$ and $2.50 \mathrm{~kg} \mathrm{Zn}$ or $2.50 \mathrm{~kg} \mathrm{Fe}$ and $1.25 \mathrm{~kg} \mathrm{Zn}$ could be due to fact that enrichment technique caused mobilization the native nutrients to increase their availability besides addition of $\mathrm{Fe}$ and $\mathrm{Zn}$ in naturally chelated form which are expected to become slowly available to growing crop over longer time.

This might helped to balance nutrition of $\mathrm{Fe}$ and $\mathrm{Zn}$ besides supplementing other essential plant nutrients and made them available to crop for longer time that causes better crop growth and yielding attributes characters. These findings are in agreement with those of Yadav et al., (2011) in wheat, Rathod et al., (2012) in maize, Bandiwaddar et al., (2016) in wheat and Parmar (2016) in fenugreek.

\section{Grain and straw yield}

An application of RDF along with $0.2 \mathrm{t}$ vermicompost $\mathrm{ha}^{-1}$ enriched with $5.00 \mathrm{~kg} \mathrm{Fe}$ and $2.50 \mathrm{~kg} \mathrm{Zn}$ produced significantly the highest grain and straw yields of wheat over rest of the treatments except treatment receiving $\mathrm{RDF}+0.2 \mathrm{t}$ vermicompost $\mathrm{ha}^{-1}$ enriched with $2.50 \mathrm{~kg} \mathrm{Fe}$ and $1.25 \mathrm{~kg} \mathrm{Zn}$ and $\mathrm{RDF}+0.5 \mathrm{t} \mathrm{FYM} \mathrm{ha}{ }^{-1}$ enriched with $5.00 \mathrm{~kg}$ $\mathrm{Fe}$ and $2.50 \mathrm{~kg} \mathrm{Zn}$. The minimum grain as well as straw yield was obtained under treatment of RDF (control). The magnitude of increase in grain and straw yields due to application of RDF along with $0.2 \mathrm{t}$ vermicompost $\mathrm{ha}^{-1}$ enriched with $5.00 \mathrm{~kg} \mathrm{Fe}$ and $2.50 \mathrm{~kg} \mathrm{Zn}\left(\mathrm{T}_{8}\right)$ was to the tune of 29.4 and 26.8 per cent, respectively over RDF (control).

Table.1 Total contents of major and micronutrients in FYM and vermicompost (before and after enrichment)

\begin{tabular}{|c|c|c|c|c|c|}
\hline \multirow[t]{2}{*}{ Organics } & \multicolumn{3}{|c|}{$\begin{array}{c}\text { Major } \\
\text { Nutrients }(\%)\end{array}$} & \multicolumn{2}{|c|}{$\begin{array}{c}\text { Micro } \\
\text { Nutrients } \\
\left(\mu \mathrm{g} \mathrm{g}^{-1}\right)\end{array}$} \\
\hline & $\mathbf{N}$ & $\mathbf{P}_{2} \mathbf{O}_{5}$ & $\mathbf{K}_{2} \mathbf{O}$ & Fe & $\mathbf{Z n}$ \\
\hline \multicolumn{6}{|l|}{ Before enrichment } \\
\hline FYM & 0.61 & 0.32 & 0.57 & 3710 & 80 \\
\hline Vermicompost & 1.41 & 1.07 & 0.61 & 4101 & 114 \\
\hline \multicolumn{6}{|l|}{ After enrichment } \\
\hline 0.5 t FYM ha ${ }^{-1}$ enriched with $5.00 \mathrm{~kg}$ Fe and $2.50 \mathrm{~kg} \mathrm{Zn}$ & 0.64 & 0.37 & 0.58 & 6054 & 160 \\
\hline $0.5 \mathrm{t} \mathrm{FYM} \mathrm{ha}^{-1}$ enriched with $2.50 \mathrm{~kg} \mathrm{Fe}$ and $1.25 \mathrm{~kg} \mathrm{Zn}$ & 0.63 & 0.36 & 0.59 & 5340 & 125 \\
\hline $0.2 \mathrm{t}$ vermicompost $\mathrm{ha}^{-1}$ enriched with $5.00 \mathrm{~kg} \mathrm{Fe}$ and $2.50 \mathrm{~kg} \mathrm{Zn}$ & 1.52 & 1.22 & 0.80 & 7040 & 210 \\
\hline $0.2 \mathrm{t}$ vermicompost $\mathrm{ha}^{-1}$ enriched with $2.50 \mathrm{~kg} \mathrm{Fe}$ and $1.25 \mathrm{~kg} \mathrm{Zn}$ & 1.48 & 1.18 & 0.78 & 6110 & 185 \\
\hline
\end{tabular}


Table.2 Effect of Fe and $\mathrm{Zn}$ enriched organics on growth, yield attributes and yields of wheat

\begin{tabular}{|c|c|c|c|c|c|c|c|c|}
\hline \multirow[t]{2}{*}{ Treatments } & \multirow{2}{*}{$\begin{array}{c}\text { Plant } \\
\text { population } \\
\text { (per meter } \\
\text { row } \\
\text { length) }\end{array}$} & \multirow{2}{*}{$\begin{array}{c}\text { Plant } \\
\text { height } \\
(\mathrm{cm})\end{array}$} & \multirow{2}{*}{$\begin{array}{c}\text { Effective } \\
\text { tillers per } \\
\text { meter }\end{array}$} & \multirow{2}{*}{$\begin{array}{l}\text { Length } \\
\text { of } \\
\text { earhead } \\
(\mathrm{cm})\end{array}$} & \multirow{2}{*}{$\begin{array}{c}\text { Grains } \\
\text { per } \\
\text { earhead }\end{array}$} & \multirow{2}{*}{$\begin{array}{l}\text { 1000- } \\
\text { grain } \\
\text { weight } \\
\text { (g) }\end{array}$} & \multicolumn{2}{|c|}{ Yield $\left(\mathrm{kg} \mathrm{ha}^{-1}\right)$} \\
\hline & & & & & & & Grain & Straw \\
\hline $\mathrm{T}_{1}: \underset{\mathrm{hDF}}{\mathrm{RD}}\left(\mathbf{1 2 0 : 6 0 : 0 0} \mathrm{kg} \mathrm{N}: \mathrm{P}_{2} \mathrm{O}_{5}: \mathrm{K}_{2} \mathrm{O}\right.$ & 48.4 & 82.1 & 80.1 & 7.65 & 29.19 & 37.7 & 4173 & 5108 \\
\hline $\mathrm{T}_{2}: \mathrm{RDF}+5$ t FYM ha ${ }^{-1}$ & 48.7 & 82.3 & 90.1 & 7.67 & 30.22 & 39.3 & 4392 & 5270 \\
\hline$T_{3}:$ RDF + 2 t VC ha ${ }^{-1}$ & 49.5 & 84.0 & 91.2 & 7.92 & 30.51 & 39.5 & 4537 & 5444 \\
\hline $\mathrm{T}_{4}: \mathrm{RDF}+5 \mathrm{t} \mathrm{FYM} \mathrm{ha}^{-1}+2 \mathrm{t} \mathrm{VC} \mathrm{ha}^{-1}$ & 49.6 & 87.5 & 92.1 & 8.28 & 31.33 & 39.8 & 4617 & 5541 \\
\hline $\begin{array}{l}\mathrm{T}_{5}: \mathrm{RDF}+0.5 \mathrm{t} \mathrm{FYM} \mathrm{ha}{ }^{-1}+5.00 \mathrm{~kg} \mathrm{Fe} \\
\text { and } 2.50 \mathrm{~kg} \mathrm{Zn} \mathrm{ha}^{-1}\end{array}$ & 49.8 & 87.8 & 94.1 & 8.39 & 33.16 & 40.1 & 4638 & 5566 \\
\hline $\begin{aligned} & \mathrm{T}_{6}: \mathrm{RDF}+0.2 \mathrm{t} \mathrm{VC} \mathrm{ha} \\
& 2.50 \mathrm{~kg} \mathrm{Zn} \mathrm{ha} \\
&\end{aligned}$ & 49.9 & 88.4 & 94.8 & 8.45 & 34.22 & 40.1 & 4649 & 5579 \\
\hline $\begin{array}{l}\text { T }_{7}: \text { RDF + } 0.5 \text { t FYM ha }{ }^{-1} \text { enriched with } \\
5.00 \mathrm{~kg} \mathrm{Fe} \text { and } 2.50 \mathrm{~kg} \mathrm{Zn}^{-}\end{array}$ & 50.5 & 92.8 & 100.4 & 8.85 & 37.54 & 41.2 & 4969 & 5963 \\
\hline $\begin{array}{l}\mathrm{T}_{8}: \text { RDF }+0.2 \mathrm{t} \text { VC ha }{ }^{-1} \text { enriched with } \\
5.00 \mathrm{~kg} \text { Fe and } 2.50 \mathrm{~kg} \mathrm{Zn}\end{array}$ & 51.3 & 97.0 & 105.4 & 9.50 & 40.77 & 43.1 & 5400 & 6480 \\
\hline 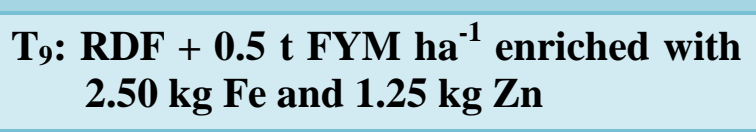 & 50.0 & 91.8 & 99.3 & 8.53 & 35.21 & 40.6 & 4785 & 5742 \\
\hline $\begin{array}{l}\mathrm{T}_{10}: \mathrm{RDF}+0.2 \mathrm{t} \mathrm{VC} \mathrm{ha}^{-1} \text { enriched with } \\
2.50 \mathrm{~kg} \text { Fe and } 1.25 \mathrm{~kg} \mathrm{Zn}\end{array}$ & 50.6 & 94.4 & 101.9 & 9.07 & 38.41 & 42.1 & 5176 & 6212 \\
\hline S.Em \pm & 1.7 & 2.9 & 3.5 & 0.34 & 1.66 & 0.8 & 209 & 251 \\
\hline C.D. $(P=0.05)$ & NS & 8.4 & 10.3 & 0.98 & 4.81 & 2.3 & 607 & 728 \\
\hline CV\% & 6.51 & 6.55 & 7.47 & 8.03 & 9.74 & 4.01 & 8.84 & 8.82 \\
\hline
\end{tabular}


The observed significant increase in grain and straw yield of wheat due to application of FYM/vermicompost enriched with either 5.00 $\mathrm{kg} \mathrm{Fe}$ and $2.50 \mathrm{~kg} \mathrm{Zn}$ or $2.50 \mathrm{~kg} \mathrm{Fe}$ and 1.25 $\mathrm{kg} \mathrm{Zn}$ might be due to fact that the soils of experimental plot was deficient in available Fe and $\mathrm{Zn}$ (Fe $4.48 \mathrm{mg} \mathrm{kg}^{-1}$ and $\mathrm{Zn} 0.38 \mathrm{mg}$ $\mathrm{kg}^{-1}$ ) and its application after enrichment of FYM/vermicompost improve its availability in soil which might have enhance the yield attributes such as plant height, length of earhead, number of grains per earhead and 1000 grain weight and finally contributed to higher grain and straw yield of wheat. These results are in the line of those reported by Yadav et al., (2011) and Rathod et al., (2012) in wheat, Parmar (2016) in fenugreek and Patel et al., (2016) in cumin.

\section{References}

Bandiwaddar T. T., Patil B. N., Patil N. K. Biradar, Desai S. A. (2016). Effect of Zinc and Iron Enriched Organics on Growth, Yield, Keeping Quality and Economics of Wheat (Triticum aestivum L.) in Maize-Wheat Sequence Cropping. Advances in Life Sciences, 5 (6):2186-2199.

Desai, D., Patel, B.T., Chaudhary, N. and Thakur, P. (2018). Status of available sulphur and cationic micronutrients in cultivated soils of Banaskantha district of Gujarat. Indian Journal of Agriculture Research, 52 (2): 203-206.

Meena, M.C., Patel, K. P. and Rathod, D.D. (2006). Effect of $\mathrm{Zn}$ and Fe enriched FYM on mustard yield and micronutrient availability in loamy sand soil (Typic Haplustert) of Anand. Journal of Indian Society of Soil Science, 54 (4): 495-499.

Parmar, S.J. (2016). Effect of iron and zinc enriched FYM on yield and quality of fenugreek. M.Sc. (Agri.) Thesis, Sardarkrushinagar Dantiwada Agricultural University, Sardarkrushinagar.

Patel. K.P., Ramani. V.P., Rathod, P.H., Patel, K.C., Kumar, D., Patel, B.K., Parmar, J.K., Jadav, N.J. (2018). 83rd annual convention of Indian Society of Soil Science \& National Seminar on developments in soil science-2018, pp- 76.

Patel, S.M., Amin, A.U. and Patel, B.T. (2016). Yield and quality of cumin as influenced by FYM enriched micronutrients. International Journal of Seed Spices. 6 (1) : 17-24.

Prasad, B. (1999). Conjoint use of fertilizers with organics, crop residues and green manuring for their efficient use in sustainable crop production. Fertilizer News,44 (5) : 67-73.

Rathod, D. D., Meena, M. C. and Patel, K. P. (2012). Evaluation of different zinc enriched organics as source of zinc under wheat-maize cropping sequences on zinc-deficient Typic Haplustepts. Journal of the Indian Society of Soil Science, 60 (1): 50-55.

Yadav, R.S., Patel, A.M., Dodia, I.N., Aglodiya, A.V., Patel, G.A. and Augustine, N. (2011). Agronomic biofortification of wheat (Triticum aestivum L.) through iron and zinc enriched organics. Journal of Wheat Research, 3 : 46-51.

\section{How to cite this article:}

Dharmesh Solanki, B. T. Patel, D. K. Patel and Suhag Chaudhary. 2020. Effect of Iron and Zinc Enriched Organics on Growth, Yield Attributes and Yield of Wheat in Loamy Sand. Int.J.Curr.Microbiol.App.Sci. 9(06): 242-247. doi: https://doi.org/10.20546/ijcmas.2020.906.030 